\title{
Dissolved Organic Carbon in Terrestrial Ecosystems: Synthesis and a Model
}

\author{
Jason C. Neff ${ }^{1 *}$ and Gregory P. Asner ${ }^{2}$ \\ ${ }^{1}$ Department of Biological Sciences, Stanford University, Stanford, California 94305, USA; and ${ }^{2}$ Department of Geological \\ Sciences and Environmental Studies Program, University of Colorado, Boulder, Colorado 80309, USA
}

\begin{abstract}
The movement of dissolved organic carbon (DOC) through soils is an important process for the transport of carbon within ecosystems and the formation of soil organic matter. In some cases, DOC fluxes may also contribute to the carbon balance of terrestrial ecosystems; in most ecosystems, they are an important source of energy, carbon, and nutrient transfers from terrestrial to aquatic ecosystems. Despite their importance for terrestrial and aquatic biogeochemistry, these fluxes are rarely represented in conceptual or numerical models of terrestrial biogeochemistry. In part, this is due to the lack of a comprehensive understanding of the suite of processes that control DOC dynamics in soils. In this article, we synthesize information on the geochemical and biological factors that control DOC fluxes through soils. We focus on conceptual issues and quantitative evaluations of key process rates to present a general numerical model of DOC dynamics. We then test the sensitivity of the model to variation in the controlling parameters to highlight both the significance of DOC fluxes to terrestrial
\end{abstract}

\section{INTRODUCTION}

Dissolved organic carbon (DOC) is present in all ecosystems. It occurs in forms that range in size from simple amino acids to complex high-molecular-weight DOC. The origin, function, and fate of

Received 14 January 2000; accepted 6 September 2000

*Corresponding author's current address: Natural Resource Ecology Laboratory, Colorado State University, Fort Collins, Colorado 80523, USA e-mail: jasonn@nrel.colostate.edu carbon processes and the key uncertainties that require additional experiments and data. Simulation model results indicate the importance of representing both root carbon inputs and soluble carbon fluxes to predict the quantity and distribution of soil carbon in soil layers. For a test case in a temperate forest, DOC contributed $25 \%$ of the total soil profile carbon, whereas roots provided the remainder. The analysis also shows that physical factors-most notably, sorption dynamics and hydrology-play the dominant role in regulating DOC losses from terrestrial ecosystems but that interactions between hydrology and microbial-DOC relationships are important in regulating the fluxes of DOC in the litter and surface soil horizons. The model also indicates that DOC fluxes to deeper soil layers can support a large fraction (up to $30 \%$ ) of microbial activity below $40 \mathrm{~cm}$.

Key words: DOC; dissolved carbon; fluxes; soil; model. these compounds in terrestrial ecosystems are only partially understood. Estimates of the role of DOC in terrestrial carbon balance are generally based on river DOC fluxes that range from 1 to $10 \mathrm{~g} \mathrm{C} \mathrm{m}^{-2}$ $\mathrm{y}^{-1}$ for many ecosystems (Hope and others 1994). These fluxes are small relative to the carbon fluxes associated with primary productivity or heterotrophic respirations in terrestrial systems (for example, Schimel 1995). For this reason, DOC fluxes are generally not considered to be important components of ecosystem carbon balance. 
Table 1. Summary of DOC Fluxes across a Range of Ecosystems

\begin{tabular}{|c|c|c|c|}
\hline Site & Vegetation Cover & $\begin{array}{l}\text { DOC Flux } \\
\left(\mathrm{gC} \mathrm{m}^{-2} \mathrm{y}^{-1}\right)\end{array}$ & Reference \\
\hline \multicolumn{4}{|l|}{ Surface $(0-20 \mathrm{~cm})$ Soil Fluxes } \\
\hline \multicolumn{4}{|l|}{ Adelaide, South Australia } \\
\hline Sandy loam & Eucalyptus Forest \& Grasses & 22 & Stevens and Cox 1999 \\
\hline Clay loam & Eucalyptus Forest \& Grasses & $2-5$ & Stevens and Cox 1999 \\
\hline Coweeta Forest, NC & Deciduous Forest & 42 & Qualls and others 1991 \\
\hline Harvard Forest, MA & Hardwood Forest & 40 & Currie and others 1996 \\
\hline Harvard Forest, MA & Coniferous Forest & 23 & Currie and others 1996 \\
\hline Hubbard Brook, NH & Hardwood Forest & 21 & McDowell and Likens 1988 \\
\hline Medicine Bows, WY & Temp. Coniferous Forest & 11 & Yavitt and Fahey 1986 \\
\hline Westlake, New Zealand & Temp. Evergreen Forest & 84 & Moore 1989 \\
\hline Westlake, New Zealand & Moss/Fern/Scrub Forest & 69 & Moore and Jackson 1989 \\
\hline Calhoun Forest, SC & Coniferous Forest & 25 & Richter and Markewitz 1996 \\
\hline Atlantic Plain, SC & Mixed Pine-Oak Forest & 13 & Dosskey and Bertsch 1997 \\
\hline $\begin{array}{l}\text { Waldstein, Bavaria, Germany } \\
\text { Jutland, Denmark }\end{array}$ & Temp. Evergreen Forest & $11-17$ & Michalzik and Matzner 1999 \\
\hline Heath & Heath & 19 & Nielsen and others 1999 \\
\hline Oak & Hardwood Forest & 26 & Nielsen and others 1999 \\
\hline Spruce & Coniferous Forest & 46 & Nielsen and others 1999 \\
\hline \multicolumn{4}{|l|}{ Subsurface $(20-100 \mathrm{~cm})$ Soil } \\
\hline \multicolumn{4}{|l|}{ Fluxes } \\
\hline \multicolumn{4}{|l|}{ Adelaide, South Australia } \\
\hline Sandy loam & Eucalyptus Forest $\&$ Grasses & $2-3$ & Stevens and Cox 1999 \\
\hline Clay loam & Eucalyptus Forest \& Grasses & $3-5$ & Stevens and Cox 1999 \\
\hline Howland Forest, ME & Coniferous Forest & 3 & Fernandez and others 1995 \\
\hline Harvard Forest, MA & Hardwood Forest & 12 & Currie and others 1996 \\
\hline Harvard Forest, MA & Coniferous Forest & 17 & Currie and others 1996 \\
\hline Hubbard Brook, NH & Hardwood Forest & 2 & McDowell and Likens 1988 \\
\hline Westlake, New Zealand & Temp. Evergreen Forest & 18 & Moore 1989 \\
\hline Westlake, New Zealand & Moss/Fern/Scrub Forest & 69 & Moore and Jackson 1989 \\
\hline Central Amazon Basin, Brazil & Trop. Evergreen Forest & 2 & McClain and others 1997 \\
\hline Central Amazon Basin, Brazil & Trop. Flooded Forest & 40 & McClain and others 1997 \\
\hline Luquillo LTER, Puerto Rico & Trop. Evergreen Forest & $4-9$ & McDowell 1998 \\
\hline Atlantic Plain, SC & Mixed Pine-Oak Forest & 6 & Dosskey and Bertsch 1997 \\
\hline \multicolumn{4}{|l|}{ Jutland, Denmark } \\
\hline Heath & Heath & 2 & Nielsen and others 1999 \\
\hline Oak & Hardwood Forest & 2 & Nielsen and others 1999 \\
\hline Spruce & Coniferous Forest & 14 & Nielsen and others 1999 \\
\hline \multicolumn{4}{|l|}{ Stream Fluxes } \\
\hline Westlake, New Zealand & Temp. Evergreen Forest & 1 & Moore 1989 \\
\hline Westlake, New Zealand & Moss/Fern/Scrub Forest & 42 & Moore and Jackson 1989 \\
\hline Hubbard Brook, NH & Temp. Deciduous Forest & 2 & McDowell and Likens 1988 \\
\hline Coweeta Forest, NC & Temp. Deciduous Forest & 2 & Meyer and Tate 1983 \\
\hline Luquillo LTER, Puerto Rico & Trop. Evergreen Forest & 3 & McDowell 1998 \\
\hline
\end{tabular}

Data are organized by surface soils (usually Oi or Oa horizons) and subsurface soils (usually B horizons).

However, there are several reasons why DOC dynamics may be more important than the relatively small fluxes to streams would suggest. First, internal system DOC fluxes are severalfold larger than stream DOC fluxes, and in some cases- particularly in northern latitudes-soluble C transport from terrestrial environments represents a substantial component of the ecosystem C balance (Table 1) (Kling and others 1991; 1992; Waddington and Roulet 1997). Second, DOC 
movement through soils is one of the important mechanisms involved in soil formation and is therefore important for understanding the distribution and stabilization of soil carbon as well as the controls over the activity of microorganisms within soil profiles (for example, McDowell and Wood 1984; Trumbore 1993). Finally, dissolved organic matter (DOM) is a vector for the loss of C, $\mathrm{N}$, and P from ecosystems. Over long time scales, small but consistent losses of DOM containing limiting or essential elements can reduce the capacity of ecosystems to support primary productivity (Hedin and others 1995; Vitousek and others 1998). For these reasons, DOC fluxes (and DOM in general) are an important component of the biogeochemistry of terrestrial ecosystems.

The dynamics of DOC fluxes have previously been addressed in models of both soil and watershed carbon dynamics (Currie and Aber 1997; Boyer and others 1996) and were recently discussed in a review article by Kalbitz and others (2000). Modeling approaches to predicting DOC fluxes include DOCMOD, which links DOC generation to biological decomposition and has been tested in northeastern hardwood forests (Currie and Aber 1997). At the watershed scale, DOC fluxes can be modeled based on relationships between water flux and the timing of DOC release from soils (Boyer and others 1996). Other modeling efforts focused on the geochemical interactions between organic compounds and mineral soil surfaces have been developed, but they are difficult to implement broadly because of the complex properties of organic compounds in soil solutions (for example, Santore and others 1995).

In this paper, we summarize the current understanding of DOC processes and dynamics in soils. The goal is to develop a general approach for a layered model of soil organic matter (SOM) cycling with an emphasis on how DOC is linked to both biological and physical processes. This effort differs from previous modeling approaches through its simultaneous treatment of physical stabilization reactions and biological production/ consumption of soluble materials and by the relative simplicity of the conceptual scheme for DOC reaction with soil/mineral surfaces. Our intent with this model is to provide a framework by which DOC cycling can be included in simulation models of ecosystem dynamics. We also use this model to highlight some of the key mechanistic uncertainties in the role of DOC in soil C cycling and ecosystem dynamics.

\section{Methods}

Field flux data. DOC fluxes have been measured in a variety of terrestrial and aquatic ecosystems, and the patterns of DOC fluxes through soil profiles suggest a set of general controls over these fluxes. The fluxes of DOC in streams have been reviewed elsewhere (Hope and others 1994), so we limit our discussion primarily to terrestrial flux studies but also discuss stream fluxes when direct comparison of riverine and terrestrial fluxes is possible. There are a number of ways to measure DOC concentrations in soils and groundwater, including tension and zero tension lysimetry, piezometers, and sampling wells. Each of these approaches may yield different results. In the review of flux data presented here, we focus primarily on data from studies using tension lysimeters (McDowell and Likens 1988; Moore 1989; Moore and Jackson 1989; Currie and others 1996; Dosskey and Bertsch 1997; Yavitt and Fahey 1986). However, we also present flux data based on a combination of lysimeters and wells (McClain and others 1997), zero tension lysimeters (Nielsen and others 1999), and piezometers (Michalzik and Matzner 1999). Although different collection methods are likely to affect concentration measurements and flux estimates, it is difficult to assess these impacts separately from the underlying variation resulting from soil and vegetation differences. For example, zero tension lysimeters may be more appropriate than tension lysimeters in sandy soils (Nielsen and others 1999). For this article, we do not directly compare fluxes obtained with different collection techniques; instead, we use the reported data to evaluate individual studies (with similar sampling techniques) for variation in DOC fluxes associated with vegetation and soil characteristics.

Physical controls. A critical assumption for DOC flux estimation and for the modeling of DOC flux controls is the relationship between hydrologic flux and DOC concentration. The papers we summarize in Table 1 use a variety of approaches to estimate soil hydrologic fluxes. These approaches include simple and complex models of hydrologic flux (for example, Sollins and McCorison 1981; Lajtha and others 1995; Currie and others 1996) as well as field measurements of soil water flow and transpiration (Brinkman 1985; Yavitt and Fahey 1986; McDowell and Likens 1988). As with the DOC collection methods, we do not attempt to evaluate the relative merits of these different flux estimate techniques. We use this review of DOC fluxes to examine the common patterns in DOC movement through terrestrial soils and then discuss the physical and bio- 
logical mechanisms that control DOC transformations.

Sorption and desorption are two key processes for DOC stabilization and production in soils. Sorption experiments are carried out over a range of time periods and with a variety of extractants, ranging from water to strong salt solutions. We summarize sorption isotherm parameters from an array of studies and soil types. We attempt to provide information for sorption dynamics under conditions similar to those occurring naturally in soils and exclude results generated in experiments with strong salt extractions. To incorporate the maximum amount of data, we do not limit the review to experiments conducted over a particular period of time or for a particular soil type. We include all the extant data with the goal of deriving the most general perspective possible from the available data.

Biological controls. Biological consumption and production of DOC may play an important role in the regulation of DOC fluxes in soils. It has been suggested that the generation of DOC by microorganisms occurs in a number of soils, but quantitative estimates of microbial production of DOC are difficult to obtain (Moller and others 1999). We summarize information from field and laboratory studies to generate a model of microbial-DOC processes and use this model to illustrate the conditions under which DOC generation by microbes is likely to be most important.

For DOC consumption (bioavailability), most studies have focused on the fraction of DOC that can be decomposed over various periods of time (Dahm 1981; Zsolnay and Steindl 1991; Qualls and Haines 1992; Jandl and Sollins 1997; Yano and others 1998). In most cases, these studies report the size of a labile fraction of DOC or a decomposition rate. Estimates of decomposition rates are difficult to simplify for modeling because they are sensitive to incubation temperatures, carbon availability, and microbial dynamics (for example, Chin-Leo and Kirchman 1990). We focus primarily on studies that partition DOC into labile and recalcitrant fractions (for example, Zsolnay and Steindl 1991). We also do not address the direct uptake of DOC by plants. Plant uptake of dissolved organic nitrogen (DON) may occur in northern latitude ecosystems (Nasholm and others 1998; Kielland 1994), but to date, only amino acid uptake has been observed. Although this may be an important source of nitrogen for plants (Chapin 1995), it is not likely to have a large impact on soil DOC fluxes because the amino acid fraction of soil organics is generally less than 2\% (Qualls and others 1991).
The TerraFlux model environment. We incorporate our DOC model within the TerraFlux ecosystem model (Asner and others forthcoming). We then use this model to simulate DOC and soil organic carbon (SOC) fluxes through the soils of a temperate forest in the northeastern United States to examine the sensitivity of DOC and SOC dynamics to variation in key parameters. Our goals in these analyses are to elucidate the potential role of DOC in soil formation processes and to highlight important areas of model/data incompatibility. The TerraFlux model (Asner and others forthcoming) combines the canopy-soil radiative transfer of Asner and Wessman (1997), a net primary productivity (NPP) approach similar to the CASA model (Field and others 1995; Asner and others 1998), and the hydrologic flux algorithms of the LSM model (Bonan 1995). TerraFlux simulates energy balance, NPP, soil hydrological processes, DOC transport and stabilization, and decomposition on an hourly time step. The hydrologic model is based on Richards' equations and has been extensively documented in the LSM User's Manual (Bonan 1996). The model has six soil layers through which water flows, based on energy and water transport equations described by Bonan (1995).

\section{RESULTS}

\section{Model Generation}

Litter layer fluxes. The soluble fluxes of organic compounds from throughfall and out of the litter layer can amount to $1 \%-19 \%$ of the total litterfall C flux and $1 \%-5 \%$ of NPP (Gosz and others 1973; McDowell and Likens 1988; Qualls and others 1991). In alder and beech forests in northern Germany, the annual soluble carbon flux from litter layer amounts to $0.8 \%-1.4 \%$ of the annual gross carbon production (Czech and Kappen 1997). Values for the potential solubility of litter in situ and in laboratory experiments range from $5 \%$ to $25 \%$ of litter dry mass and $5 \%$ to $15 \%$ of litter C content (McDowell and Likens 1988; Zsolnay and Steindl 1991). Each precipitation event that causes water movement through litter will lead to a flux of soluble materials. In crop residues, this fraction is as much as $1 \%$ per simulated rainfall event, and there are indications that the soluble litter fraction becomes depleted at higher rainfall intensities (Schreiber and McDowell 1985). Repeated leaching of organic materials also indicates that this short-term depletion of the DOC flux capacity is a transient effect (Neff and others 2000).

Soil DOC fluxes. Fluxes of DOC generally decrease from the litter layer to deeper mineral hori- 
zons (Table 1). In virtually every soil with substantial clay content, DOC concentrations drop by $50 \%-$ $90 \%$ from the surface organic layers to subsurface mineral soils (McDowell and Wood 1984; Cronan and Aiken 1985; Dalva and Moore 1991; Koprivnjak and Moore 1992; Dosskey and Bertsch 1997). Surface soil fluxes of DOC range from 10 to $85 \mathrm{~g} \mathrm{C}$ $\mathrm{m}^{-2} \mathrm{y}^{-1}$; below the surface horizons, they decline to $2-40 \mathrm{~g} \mathrm{C} \mathrm{m}^{-2} \mathrm{y}^{-1}$ (Table 1). DOC fluxes vary from 1 to $10 \mathrm{~g} \mathrm{C} \mathrm{m}^{-2} \mathrm{y}^{-1}$ in streams, but a few substantially higher fluxes can occur in drainages containing sandy or highly organic soils (Moore and Jackson 1989; Hope and others 1994). Measurements of DOC fluxes in eucalyptus forests in Australia also show higher DOC fluxes in sandy vs. clayey soils (Stevens and Cox 1999). Similar patterns are observed in Amazonian forests growing on sandy soils (McClain and others 1997). Comparisons of DOC concentrations in soils below pine, prairie, and corn vegetation all show similar patterns to those in Table 1, with increased DOC concentrations at a soil depth of $25 \mathrm{~cm}$ relative to throughfall and substantial decreases in concentration with depth to $140 \mathrm{~cm}$ (Quideau and Bockheim 1996). DOC leaching in the prairie soil was barely detectable in the Quideau and Bockheim study (1996), and concentrations were substantially higher under both corn and pine forests than in prairie soils. Similar results have been observed in forest/agricultural soil comparisons in Japan (Seto and Yui 1983). These results suggest that forested ecosystems probably support larger DOC fluxes than grassland and perhaps agricultural ecosystems, but information is scarce and additional studies are needed.

Soil DOC sorption. Organic materials form a variety of bonds with soil surfaces. Organic-mineral interactions range in strength from strong ligand exchange to weaker anion exchange reactions (McBride 1994). The type of mineral-organic association can vary depending on the characteristics of both the soil surface and the organic molecule, complicating conceptual models of these processes. There is a large body of literature on metal-DOC interactions and multiple approaches to detailed modeling of soil abiotic processes (for example, Cosby and others 1985; Furrer and others 1990). Detailed metal-DOC reactions have also been linked to soil biogeochemistry; these relationships can help in understanding the long-term stabilization of DOC into organometalic complexes (Santore and others 1995). In this review, we focus on a simplified approach to modeling DOC sorption both to make straightforward linkages to ecosystem models and to take advantage of general relation- ships linking soil properties to sorption properties across a range of soil types.

Sorption isotherms are commonly used to examine relationships between solution concentration and soil surface association. Because DOC moves in and out of solution continuously in soils, the Initial Mass (IM) isotherm best represents DOC sorption reactions (Nodvin and others 1986) and is represented by the following linear isotherm:

$$
R E=m X_{i}-b
$$

where $R E$ is the amount of DOC released into or removed from solution, $m$ is the dimensionless regression (partition) coefficient, $X_{i}$ is the initial concentration of DOC (mg g soil $\left.{ }^{-1}\right)$, and $b$ is the intercept (mg DOC released per gram soil if $X_{i}=0$ ). Functionally, $m$ and $b$ can be viewed as measures of a soil's tendency to adsorb and release DOC. Another useful aspect of the IM isotherm is that it can be used to estimate the size of a reactive soil pool (RSP) (Nodvin and others 1986). This pool, defined as:

$$
R S P=\frac{b}{(1-m)}
$$

represents the soil C pool that may be lost to leaching (Table 2).

A summary of sorption data for a number of soil types is shown in Table 2. These data are based on average values obtained from a range of sites and studies (see Appendix). Several broad patterns are evident in Table 2, including a general increase in $m$ and decrease in $b$ with soil depth and some indication that certain soil types have a greater affinity for DOC than others. The affinity of soils for DOC is closely linked to several soil properties. There are generally positive correlations between $m$ and soil clay content, dithionite extractable iron $\left(\mathrm{Fe}_{\mathrm{d}}\right)$, and oxalate extractable aluminum $\left(\mathrm{Al}_{\mathrm{o}}\right)$ (Table 3) (Moore and others 1992; Nelson and others 1993; Kaiser and others 1996; Kaiser and Zech 1998). These soil properties likely correlate with DOC sorption because they are indicators of the reactive soil surface area available for ionic and physical associations. Direct measurements of surface area also correlate very well with DOC adsorption capacity (Nelson and others 1993), but these measurements have not been made in conjunction with sorption isotherms in many types of soil. These basic relationships represent mineralogical controls over DOC stabilization and likely contribute to the observed correlation between soil texture and SOM content (Schimel and others 1994; Christensen 1996). 
Table 2. Sorption/Desorption Values at the Soil Order Level

\begin{tabular}{|c|c|c|c|c|}
\hline Soil Order & $\mathrm{m}$ & $\mathrm{b}(\mathrm{mg} / \mathrm{g})$ & RSP & Number of sites \\
\hline \multicolumn{5}{|l|}{ Spodosols } \\
\hline $\mathrm{A}$ & $0.31(0.08)$ & $0.21(0.09)$ & $0.39(0.21)$ & 3 \\
\hline $\mathrm{B}$ & $0.73(0.06)$ & $0.34(0.07)$ & $2.42(0.57)$ & 14 \\
\hline C & $0.71(0.10)$ & $0.34(0.09)$ & $1.72(0.70)$ & 5 \\
\hline \multicolumn{5}{|l|}{ Oxisols } \\
\hline \multicolumn{5}{|l|}{ A } \\
\hline B & $0.28(0.07)$ & $0.03(0.03)$ & $0.06(0.06)$ & 2 \\
\hline \multicolumn{5}{|l|}{ Ultisols } \\
\hline A & $0.47(0.16)$ & $0.09(0.03)$ & $0.11(0.06)$ & 2 \\
\hline B & 0.64 & 0.01 & 0.06 & 1 \\
\hline \multicolumn{5}{|l|}{ Mollisols } \\
\hline A & 0.01 & 0.78 & 0.78 & 1 \\
\hline B & 0.70 & 0.2 & 0.59 & 1 \\
\hline C & 0.28 & 0 & 0 & 1 \\
\hline \multicolumn{5}{|l|}{ Alfisols } \\
\hline A & 0.57 & 0.41 & 0.95 & 1 \\
\hline $\mathrm{B} / \mathrm{C}$ & 0.76 & 0.05 & 0.20 & 1 \\
\hline \multicolumn{5}{|l|}{ Inceptisols } \\
\hline A & $0.07(0.04)$ & $0.74(0.10)$ & $0.82(0.15)$ & 4 \\
\hline $\mathrm{B}$ & $0.55(0.06)$ & $0.18(0.04)$ & $0.42(0.10)$ & 11 \\
\hline $\mathrm{C}$ & $0.58(0.07)$ & $0.09(0.02)$ & $0.27(0.07)$ & 5 \\
\hline
\end{tabular}

Data compiled from Dalva and Moore 1991; Kaiser and others 1996; Moore and others 1992; Nodvin and others 1986; Qualls and Haines 1992; Vance and David 1992; Neff 1999. $M$ (sorption affinity), $b$ (desorption parameter), RSP (reactive soil pool).

Table 3. Controls over DOC Sorption and Desorption across a Range of Soil Types

\begin{tabular}{|c|c|c|c|}
\hline Soil Type & Relationship & $r^{2}$ & Reference \\
\hline \multicolumn{4}{|l|}{ Sorption Affinity (m) } \\
\hline $\begin{array}{l}\text { Spodosols, inceptisols, alfisols, } \\
\text { entisols, and mollisols }\end{array}$ & $\mathrm{m}=0.64+0.15 \log \mathrm{Fe}+0.19 \log \mathrm{Al}-0.26 \log \mathrm{OC}$ & 0.75 & $\begin{array}{l}\text { Kaiser and others } \\
1996\end{array}$ \\
\hline $\begin{array}{l}\text { Inceptisols, spodosols, and } \\
\text { mollisols }\end{array}$ & $\begin{array}{l}\mathrm{m}=0.451+0.021 \log \mathrm{Fe}+0.032 \mathrm{VAl}+ \\
0.064 \operatorname{logOC}\end{array}$ & 0.39 & $\begin{array}{l}\text { Moore and others } \\
1992\end{array}$ \\
\hline $\begin{array}{l}\text { Ultisols, spodosols, inceptisols, } \\
\text { and oxisols }\end{array}$ & $\mathrm{m}=0.15 \ln (\%$ soil $C)+0.51$ & 0.41 & $\begin{array}{l}\text { Studies with } \mathrm{m} \text { and } \\
\% \mathrm{C} \text { values from } \\
\text { Appendix }\end{array}$ \\
\hline \multicolumn{4}{|l|}{ Desorption Parameter (b) } \\
\hline $\begin{array}{l}\text { Spodosols, inceptisols, alfisols, } \\
\text { entisols, and mollisols with } \\
\text { carbonates }\end{array}$ & $\log b=0.32+0.72 \log \mathrm{OC}$ & 0.76 & $\begin{array}{l}\text { Kaiser and others } \\
1996\end{array}$ \\
\hline $\begin{array}{l}\text { Spodosols, inceptisols, alfisols, } \\
\text { entisols, and mollisols } \\
\text { without carbonates }\end{array}$ & $\log b=-0.02+0.88 \log \mathrm{OC}$ & 0.82 & $\begin{array}{l}\text { Kaiser and others } \\
1996\end{array}$ \\
\hline $\begin{array}{l}\text { Inceptisols, spodosols, and } \\
\text { mollisols }\end{array}$ & $\begin{aligned} \mathrm{b}= & 0.145+0.103 \log \mathrm{OC}-0.055 \mathrm{VAl}- \\
& 0.045 \log \mathrm{Fe}\end{aligned}$ & 0.72 & $\begin{array}{l}\text { Moore and others } \\
\quad 1992\end{array}$ \\
\hline $\begin{array}{l}\text { Ultisols, spodosols, inceptisols, } \\
\text { and oxisols }\end{array}$ & $\mathrm{b}=0.05(\%$ soil $C)+0.09$ & 0.48 & $\begin{array}{l}\text { Studies with } \mathrm{m} \text { and } \\
\% \mathrm{C} \text { values from } \\
\text { the Appendix }\end{array}$ \\
\hline
\end{tabular}

There can be both positive and negative relationships between sorption affinity $(m)$ and the SOM content of soils that complicate prediction of how $m$ varies within and between soil types. The sorption affinity $(m)$ and the soil carbon content are inversely related in some studies (Jardine and others 

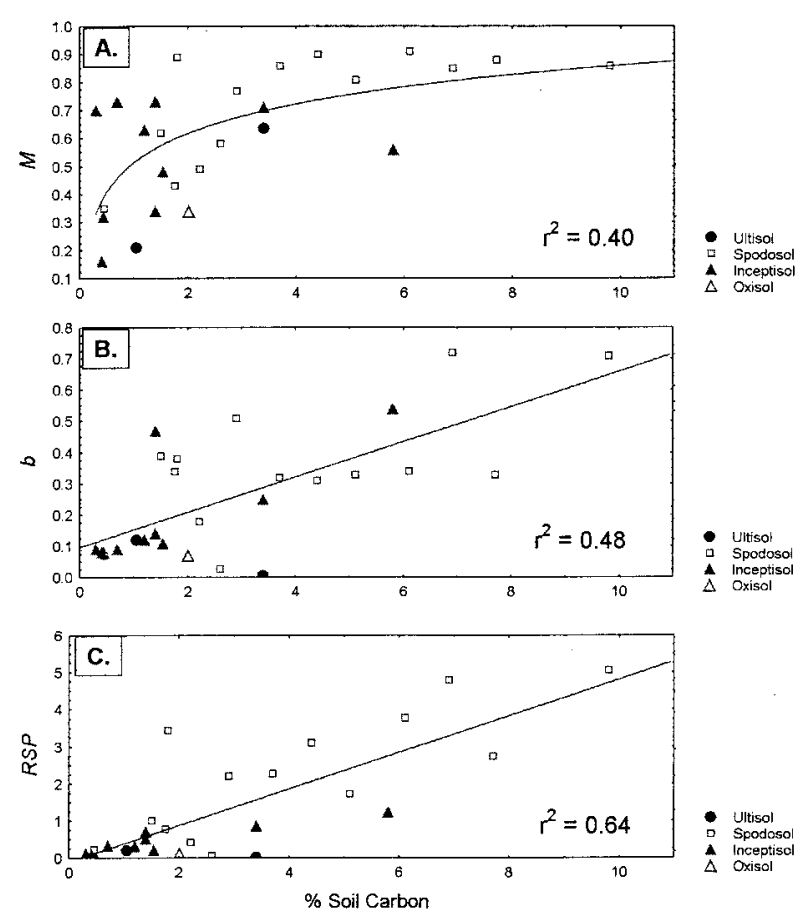

Figure 1. Sorption parameters plotted against percentage of soil carbon and separated by soil type. Data are based on studies cited in the Appendix. The curve fit in (A) is based on a log function. Curve fits in panels (B) and (C) are based on linear functions.

1989; Kaiser and others 1996) and positively related in others (Moore and others 1992). Solid organic matter can provide a major source of charged surfaces for ionic associations and therefore contribute to the sorption capacity of a soil. Conversely, the presence of organic matter can fill existing mineral surfaces and thus reduce DOC sorption under certain conditions (Sollins and others 1995). There is currently not enough information to understand why the relationship between the sorption affinity $(m)$ and soil $\mathrm{C}$ varies between studies, but at a broader scale, there is a strong positive relationship between $m$ and soil C content (Figure 1). This relationship may reflect underlying differences in the $\mathrm{C}$ sorption capacity (and therefore SOM content) of different soil types. Additional cross-system sorption measurements and comparisons are needed before this can be evaluated. The various relationships between sorption parameters and soil mineralogical and carbon content are summarized in Table 3 .

Controls of DOC desorption. There are strong relationships between DOC desorption and a variety of soil properties. At the scale of soil orders, there appears to be a correspondence between the parameters $b$ and RSP and soil carbon content (Figure
1). These relationships also hold at local to regional scales (Table 3) (Moore and others 1992; Vance and David 1992; Kaiser and others 1996), yet they also include negative, but less significant, relationships of $b$ with dithionite extractable iron and oxalate extractable aluminum (Moore and others 1992).

The $b$ and soil carbon relationship reflects a rapid equilibration between dissolved and solid organic matter (McDowell and Wood 1984). This observation is supported by evidence of strong similarities between the NMR spectra of DOC humic fractions and solid SOM (David and others 1995). These results indicate that there is generally a reactive or soluble fraction of the total SOM pool that may be solubilized and lost to either microbial decomposition or leaching (Vance and David 1992). Relationships between $b$ and SOM are useful for modeling because they allow linkage between a relatively well-known property of soils (organic $\mathrm{C}$ content) and a key parameter for representing DOC production in soils.

Biological production of DOC. Soluble root exudates and microbial processes can contribute substantial amounts of dissolved $\mathrm{C}$ to the belowground environment. The flow of soluble $\mathrm{C}$ through root exudates into the soil can be a significant fraction of total plant $\mathrm{C}$ fixation, reaching as high as $17 \%$ in grassland ecosystems (Biondini and others 1988). These high fluxes could explain much of the observed dissolved material coming from upper soil layers in most ecosystems (Table 1). However, only a small fraction of plant $\mathrm{C}$ appears to make it to the water soluble component of soil organic matter (WSOM). In wheat and barley crops, less than $2 \%$ of an added ${ }^{14} \mathrm{C}$ pulse could be found in the WSOM fraction, whereas $15 \%-25 \%$ of the added pulse was respired from roots and the rhizosphere (Gregory and Atwell 1991). These results, combined with evidence showing that soil solution DOC consists of substantially degraded plant or microbial materials (Guggenberger 1994), make it unlikely that plant root (or throughfall/litter leachate) DOC is significant in direct exchange reactions or microbial processes within the soil environment. Nonetheless, the controls over plant exudate release and microbial utilization of exudates remain poorly understood, and plant roots cannot be ruled out as a direct source of DOC to upper soil layers.

Microbial control of DOC production is frequently mentioned in studies of DOC cycling; it is represented explicitly, albeit simply, as a parameterized component of the Century model (Parton and others 1994). Several lines of evidence link microbial activity and DOC concentrations, but the results are somewhat contradictory. There is evi- 
dence of both strong correlations between DOC concentrations and soil $\mathrm{CO}_{2}$ evolution (Seto and Yanagiya 1983; Jandl and Sollins 1997) and weaker relationships between these factors (Cook and Allen 1992; Neff and others 2000). Laboratory experiments of DOC generation have also found increased release rates at higher temperatures, with $\mathrm{Q}_{10}$ values similar to laboratory studies of temperature effects on $\mathrm{CO}_{2}$ efflux, suggesting some degree of biological control over DOC generation (Christ and David 1996; Toland and Zak 1994). Losses of DOC from the litter layer increase with temperature, and relationships between DOC production and $\mathrm{CO}_{2}$ evolution in the forest floor suggest a link between overall microbial activity and DOC generation (Göedde and others 1996). A close correlation $\left(r^{2}=0.96\right)$ between water extractable organic carbon and total mineralizable organic $\mathrm{C}$ suggests a link between DOC and total labile C in soils (Burford and Bremner 1975). In plot-scale studies of microbial activity with and without litter, Jandl and Sollins (1997) concluded that DOC also plays an important role as a substrate for microbial activity.

The interpretation of DOC flux or concentration/ $\mathrm{CO}_{2}$ production relationships is complicated by the difficulty of establishing the direction of causation. In correlative experiments, it is impossible to determine whether microbial activity occurs because DOC is present or vice versa (for example, Brooks and others 1999). Observations of chemical transformations of DOC during transport from the litter layer into soils suggest that some fraction of microbial structure becomes DOC (Guggenberger and Zech 1992). The actual situation in soils is likely to involve all aspects of these transformations. In surface litter layers and soils, where there are substantial inputs of relatively labile soluble materials, microbial communities likely use a substantial fraction of the DOC as a substrate for growth (Dahm 1981; Jandl and Sollins 1997). As DOC moves deeper into the soils, its biological availability decreases, reflecting either the transport of residual, recalcitrant components of the DOC, or a physical desorption/ dissolution flux of C from SOM to DOM (Qualls and Haines 1992).

A direct link between microbial activity and DOC generation seems likely; indirect links between biological availability and physical DOC generation are also possible (Moller and others 1999). Biological mechanisms such as bioturbation can cause changes in the structure of soil aggregates (for example, Albrecht and others 1998) and may indirectly control rates of DOC release by changing the surface area of soils available for desorption. The strong relationship between soil organic carbon content and soil DOC concentration argues for at least partial physical control over DOC generation. Based on these complex relationships and the lack of a clear and consistent pattern, there is good reason to represent both biological and physical controls over DOC release in conceptual and numerical models.

Biological consumption of DOC. The distinction between biologically available and unavailable DOC is important to both conceptual and simulation models of DOC biogeochemistry, but unfortunately, this is an area in which mechanistic information is critically lacking. The simplest representation of the DOC pool is as a combination of labile and recalcitrant fractions, and only a handful of experiments have attempted to partition these fractions by examining how much terrestrial DOC can be decomposed in a fixed period of time (usually a period of weeks to months). Initial rates of DOC decomposition in incubation experiments are generally rapid but then decline quickly to a lower, constant rate (Boissier and Fontvieille 1993; Zsolnay and Steindl 1991). In general, DOC bioavailability declines as organic materials move from throughfall to depth in soils. In throughfall, about $18 \%-50 \%$ of the DOC can be viewed as biologically available or labile, with some indications of seasonal variation in the size of this fraction (Qualls and Haines 1992; Yano and others forthcoming). In litter leachate, the bioavailable fraction ranges from $6 \%$ to $20 \%$ (Dahm 1981; Qualls and Haines 1992), and in forest soils, the size of the bioavailable fraction ranges between $5 \%$ and 16\% (Qualls and Haines 1992; Jandl and Sollins 1997; Yano and others 1998, forthcoming). The reduction in bioavailable DOC with soil depth is not always observed. In some agricultural soils, there is a large and relatively constant bioavailable fraction of $55 \%$ at multiple soil depths (Zsolnay and Steindl 1991). Similarly, the bioavailability of DOC under cool and warm-season grasses and forests averages $41 \%$ above $60 \mathrm{~cm}$ and $47 \%$ below the 60 $\mathrm{cm}$ soil depth (Corre and others 1999). The range of reported values and the variety of experimental approaches determining bioavailable DOC, as well as the difficulty in interpreting relationships between DOC concentrations and decomposition rates, indicate that detailed chemical and/or isotropic analyses of microbial and DOC characteristics are still needed to clarify relationships between DOC and microbial communities in soils.

Hydrologic control over DOC fluxes. Hydrologic conditions influence leaching and apparent reactivity of dissolved organic material in terrestrial ecosystems and represent one of the most basic but frequently overlooked aspects of soluble element 


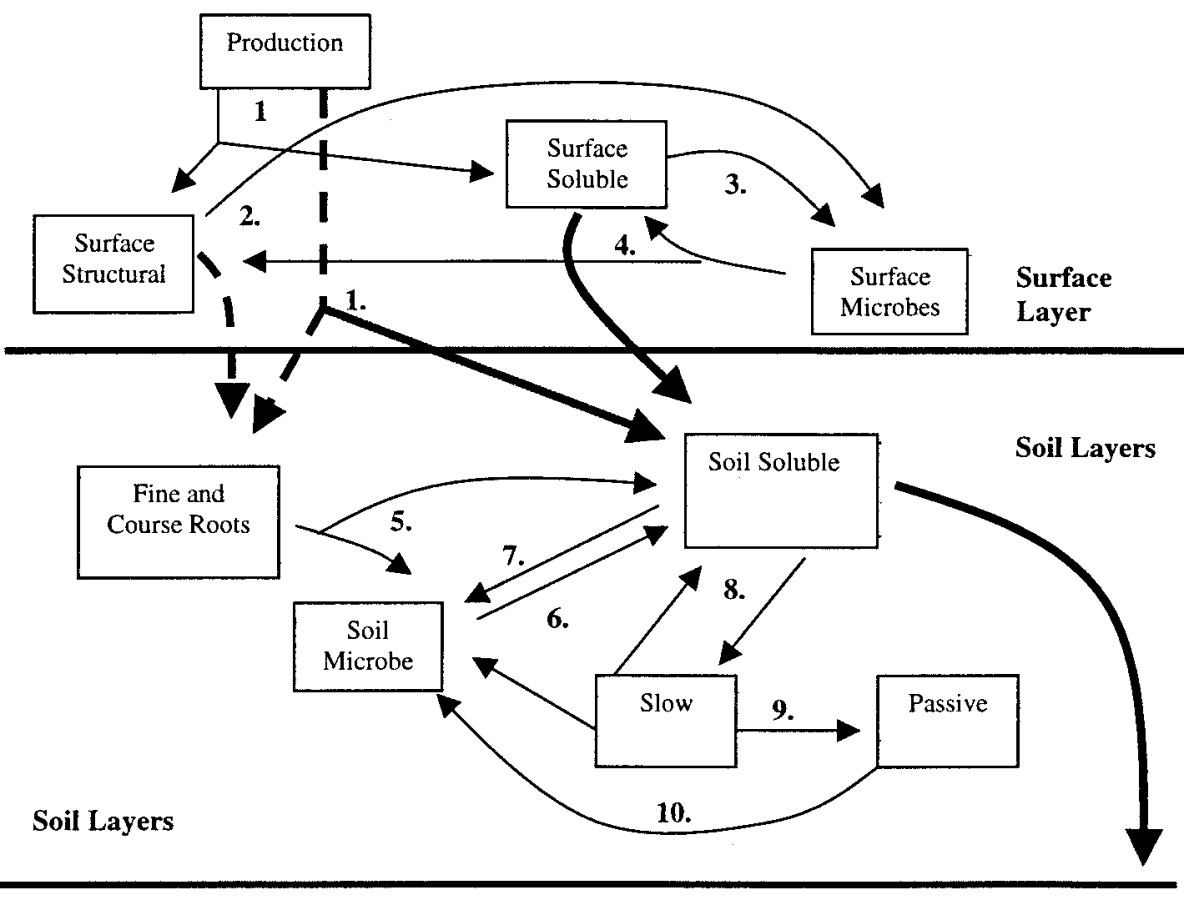

Figure 2. DOC model structure. Numbers refer to control points referenced below. Heavy solid lines show dissolved material transfers between layers; heavy dashed lines show solid SOM transfers between layers.

1. $\mathrm{S}_{\text {(fine litter, fine roots) }}=0.25-(0.018 * \mathrm{LN})$ and $\mathrm{S}_{\text {(coarse woody debris) }}=0.05-(0.005 * \mathrm{LN})$

2. Surface structural decomposition, annual $k=3.9$

3. Parameterized: bioavailability sensitivity test in Table 4.

4. Parameterized: solubility sensitivity test in Table 4.

5. Same as flow \#1.

6. Parameterized: solubility sensitivity test in Table 4 .

7. Parameterized: bioavailability sensitivity test in Table 4 .

8. $d C_{\text {slow }} / d t=m[D O C]-b\left[C_{\text {slow }}\right]-F p-F m . m$ is parameterized, $F m$ is based on a turnover time of $0.1 \mathrm{y}^{-1}$ and $b$ varies according to the following relationship; $b=b_{\max } * \%$ Soil Carbon $/(\%$ Soil Carbon +1$)$

9. $F p$ is parameterized following the Century model (Parton and others 1994).

10. Annual $k=0.0045$ (Parton and others 1994).

fluxes. Within soils, factors such as hydraulic conductivity and the capacity for bypass flow affect concentrations and fluxes of inorganic elements in solution (for example, Prendergast 1995), and it is likely that DOC behaves similarly (Radulovich and others 1992). There is also evidence that water flow rate through soils affects the physical reactivity of DOC. In a laboratory experiment using goethitecoated sands, a $50 \%$ increase in pore water velocity led to an $18 \%$ decrease in the slope of the adsorption isotherm and an $83 \%$ increase in the desorption coefficient (Weigand and Totsche 1998).

Model structure. We incorporated the described mechanisms of DOC generation, consumption and stabilization into a model that represents biological production and consumption fluxes as well as physical sorption and desorption processes. The DOC model interacts with a soil carbon model in TerraFlux that incorporates the basic aspects of the Century model (Parton and others 1987), with the important distinction that TerraFlux simulates mul- tiple layers of soil C. Carbon enters the soil through surface litterfall-partitioning equations of Parton and others $(1987,1994)$ and Randerson and others (1996) and through root turnover and partitioning. Allocation of root carbon is based on site-level data; for this paper, it was specified by layer as $40 \%$, $35 \%, 15 \%$, and $10 \%$ for layers from 0 to $10 \mathrm{~cm}, 10$ to $30 \mathrm{~cm}, 30$ to $70 \mathrm{~cm}$, and 70 to $140 \mathrm{~cm}$.

We have maintained the soil carbon pool structure of the Century model for each soil layer in TerraFlux and include active, slow, and passive soil organic carbon (SOC) pools (Parton and others $1987,1994)$. Each of these pools is characterized by different turnover times ranging from months (active; approximately 2-3 months) to decades (slow; around 10 years) and centuries (passive; around 250 years). Physically, these pools correspond to a combination of microbes and microbial metabolites (the active pool), chemically recalcitrant but moderately decomposable material (the slow pool), and a physically and chemically protected pool of car- 
bon that is very resistant to decomposition (the passive pool). Both temperature and moisture influence decomposition rates for each of the pools with the relationships described by Parton and others (1987).

The model for DOC turnover and transport process is described by the following equations and is shown graphically in Figure 2. We use the general relationship between lignin: $N$ and solubility described by Parton and others (1994) to scale the soluble fraction of the standing litter pool from 5\% to $25 \%$. These relationships are used in the Century model to represent the decomposability of litter by splitting the incoming litter $\mathrm{C}$ pool into structural and decomposable fractions, both of which are assumed to be solid. In the Century model, the structural-decomposable split is based on laboratory assays that link hot water soluble litter materials (the functional definition of the metabolic pool) to the lignin:N ratio of the litter (Parton and others 1994). This hot water soluble fraction of litter varies from $10 \%$ to $60 \%$ across a wide range of vegetation types, but most values fall between $20 \%$ and $40 \%$. Because the soluble fraction of litter is also relatively decomposable, we represent only the structural portion of litter as a solid fraction and link the movement of the labile fraction to the flux of water through the litter layer with the following equations:

$$
\begin{aligned}
& S_{f l, f r}=0.25-(0.018 \times L N) \\
& S_{f c w d}=0.05-(0.005 \times L N)
\end{aligned}
$$

where $S_{f l}$ is the soluble litter fraction, $S_{f r}$ is the soluble fraction of roots, $S_{f c w d}$ is the soluble fraction of the course woody debris at each time step, and $L N$ is the lignin:nitrogen ratio of the incoming litter. DOC fluxes are calculated as the product of the hydrologic flux and the concentration of soluble material in the litter layer. In the simulations described later in this article, we assume that litter and roots have similar solubilities (and controls over solubility).

Sorption and desorption processes in the model are calculated with the sorption isotherm described in Eq. (1). The change in the slow carbon pool content in each soil layer is calculated as

$$
\frac{d C s l o w}{d t}=m[D O C]-b[C s o w]-F p-F m
$$

where $m$ and $b$ are the sorption and desorption parameters described in Eq. (1), Fp is the flow to the passive pool, and $F m$ is the microbial decomposition of solid slow SOM. Both Fp and Fm are similar to the fluxes of carbon from the slow pool described for the Century model (Parton and others 1987).

For simulations, we represent desorption as a function of the mass of carbon in the soils in accordance with the data in Table 2. We have adopted an equation to represent the general relationship between SOM C content and the $b$ based on the data presented in the literature review. The following equation scales the desorption flux with soil carbon up to a maximum (on a per gram soil basis) determined from Table 2:

$$
b=b_{\max } * \frac{\% \text { Soil Carbon }}{\% \text { Soil Carbon }+1.0}
$$

where $b$ represents the desorption coefficient in Eq. (1) and $b_{\max }$ is the soil-specific maximum desorption parameter (Table 2). For the modeling exercises below, we simply assign a value for $m$ from the spodosol average $m$ shown in Table 2 and explore the sensitivity of the model to different sorption affinities.

DOC is generated in the model during microbial decomposition as the product of the turnover time of the microbial pool and the fraction of microbial biomass that becomes soluble during turnover. The estimate for the size of this soluble fraction is based on a midpoint value of $50 \%$ taken from studies of microbial biomass measurement techniques (Beck and others 1997). For microbial uptake of DOC, the DOC pool is considered to contain a labile fraction that is immediately available for microbial uptake and a recalcitrant fraction that cannot be taken up during a model time step.

Both the bioavailable fraction of DOC and the soluble fraction of decomposing microbes are retained as explicit fixed parameters because there is not sufficient information to use a more mechanistic representation for these values. However, there are sufficient data to explore a range of values that represents their likely variation; these results are described in the Model Results section below.

To express the relationship between DOC reactivity and hydrologic flux rates, we reduce the sorption affinity $m$ by a modifier term $(\mathrm{Hm})$ that scales with the rate of solution movement through the soil $(m=m-H m)$. This parameterization represents a kinetic aspect of the sorption reactions and a maximum flow rate induced variation in $m$ of $20 \%$ in a soil with $100 \%$ clay content:

$$
H m=m \times 0.2\left(\frac{v}{v_{s}}\right)\left(\frac{\% \text { Clay }}{100}\right)
$$

where $v$ is actual pore water velocity determined 
Table 4. Parameters Used for Sensitivity Analyses

\begin{tabular}{|c|c|c|c|c|}
\hline & Bioavailability $^{a}$ & Solubility $^{b}$ & $\begin{array}{l}\text { Sorption }^{c} \\
\text { (m) }\end{array}$ & $\begin{array}{l}\text { Desorption } \\
\text { (b) }\end{array}$ \\
\hline Base Case & 0.3 & 0.5 & 0.3 & 0.15 \\
\hline Low Bioavailability & 0.1 & 0.5 & 0.3 & 0.15 \\
\hline High Bioavailability & 0.5 & 0.5 & 0.3 & 0.15 \\
\hline Low Solubility & 0.3 & 0.3 & 0.3 & 0.15 \\
\hline High Solubility & 0.3 & 0.7 & 0.3 & 0.15 \\
\hline Low Sorption & 0.3 & 0.5 & 0.1 & 0.15 \\
\hline High Sorption & 0.3 & 0.5 & 0.5 & 0.15 \\
\hline Low Desorption & 0.3 & 0.5 & 0.3 & 0.05 \\
\hline High Desorption & 0.3 & 0.5 & 0.3 & 0.25 \\
\hline
\end{tabular}

from the TerraFlux hydrologic model and $v_{s}$ is the pore water velocity at saturated conditions, which is a soil-specific parameter. The equation scales with clay content because the rate of sorption does not appear to be affected by hydrologic flux rates in sandy soils (Weigand and Totsche 1998).

In contrast to the sorption flux, the desorption flux is driven by concentration gradients and increases with solution flow (Weigand and Totsche 1998). Thus, $b$ is increased $(b=b+H b)$ by

$$
H b=b \times 0.2\left(\frac{v}{v_{s}}\right)\left(\frac{\% \text { Clay }}{100}\right)
$$

As with the down-regulating $\mathrm{Hm}$ modifier, $\mathrm{Hb}$ scales with flow velocity and percentage of clay content, but in contrast to flow effects on $m, b$ is incremented by $\mathrm{Hb}$ to establish a flow-dependent desorption coefficient. The Terraflux model also includes representation of bypass flow that is proportional to the root biomass in each layer and is used to route DOC directly to deeper soil layers (Asner and others forthcoming). For all layers, DOC is leached from each soil layer as a function of its concentration multiplied by the volume of water flux.

\section{Model Results}

In the following analyses, we use the basic parameterizations (for example, precipitation and temperature) for a temperate forest with $1500 \mathrm{~mm}$ of rain and a mean annual temperature of $9^{\circ} \mathrm{C}$ to show the sensitivity of dissolved carbon fluxes to variation in the DOC control parameters. The basic parameters used for the base case and various sensitivity analyses are shown in Table 4 . The base case parameters represent midpoint values for the A horizon of a spodosol and are bounded by the high and low ends of values for sorption and desorption presented for a range of soil types in Table 2 . These parameters were chosen to capture the physical attributes of a range of temperate forests. We then compare our results to soil DOC flux data from temperate forests in the United States and Europe. However, we also note that the range of values in the sensitivity analysis cover most of the variation in sorption parameters for the broad range of soils shown in Table 2 . For the bioavailability and solubility parameters, we also have taken midpoints from the data ranges presented in the Model Generation section of this article. In the case of solubility of the products of microbial turnover, for which there is little data, the base case parameter is simply the midpoint of a potential range for microbial solubility (Beck and others 1997). We present our model results as the fluxes from a litter layer and include the humidified organic rich surface horizons as the top portion of our modeled soil profile (represented by the DOC fluxes reported for the $5-\mathrm{cm}$ soil depth).

The range of flux values generated for the simulations were $48-52 \mathrm{~g} \mathrm{DOC} \mathrm{m}^{-2} \mathrm{y}^{-1}$ for leaching

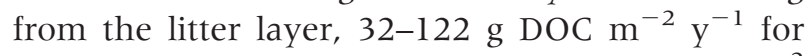
leaching at a soil depth of $5 \mathrm{~cm}, 3-27 \mathrm{~g} \mathrm{DOC}^{-2}$

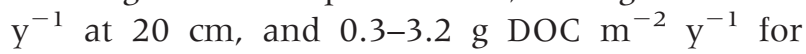
leaching from a depth from $50 \mathrm{~cm}$ (Figure 3). The modeled leaching for the litter layer is higher than temperate forest litter layer leaching rates of 20-40 g DOC $\mathrm{m}^{-2} \mathrm{y}^{-1}$ reported by Currie and others (1996) and McDowell and Likens (1988), but it is in the upper portion of the range of surface soil fluxes, including rates of $46 \mathrm{~g} \mathrm{DOC}^{-2} \mathrm{y}^{-1}$ at a soil depth 


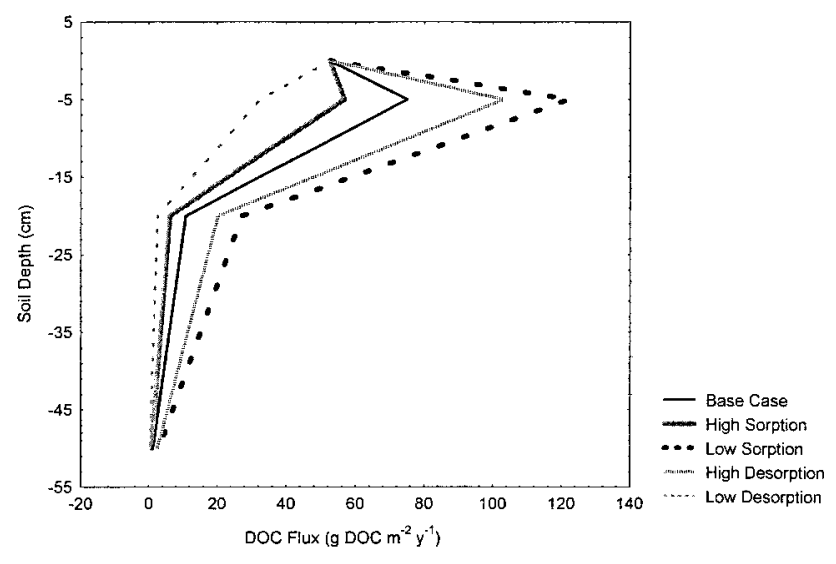

Figure 3. Sensitivity of soil DOC fluxes to variation in sorption and desorption parameters. Base case and high and low sorption/desorption values are given in Table 4 .

of $10 \mathrm{~cm}$ in a Sitka spruce forest in Denmark reported by Nielsen and others (1999). Modeled DOC fluxes were generally larger in the $5-\mathrm{cm}$ model soil depth than in the surface soil fluxes reported in Table 1. However, most of the measurements listed in Table 1 are made between 10 and $20 \mathrm{~cm}$ and are more similar to model fluxes at $20 \mathrm{~cm}$. At the 20 and $50-\mathrm{cm}$ soil depths in the model, DOC fluxes were similar to the range of fluxes reported in Table 1 for surface and subsurface soils, respectively.

The model results showed strong relationships between water flux and DOC flux, with signs of hysterisis in the top $0-10 \mathrm{~cm}$ of soil. In all other soil layers, the hydrologic/DOC flux relationships were linear when summed to weekly fluxes, implying that hydrologic flux rates rather than production mechanisms were limiting to the net flux (Figure 4). Two aspects of these model results highlight the importance of water flux to DOC transport. First, in the top $10 \mathrm{~cm}$ of soil, $30 \%$ of the DOC flux (in the base case) resulted from 4 weeks with large storm events (Figure 4). Substantial amounts of DOC are also transported during small rain events, particularly in the surface litter layer, which has a limited capacity for water retention. In the surface litter layer, the model predicts that approximately $60 \%$ of DOC fluxes are associated with very small rain events (less than $1 \mathrm{~mm}$ per day) as water flushes into the surface soil.

The strongest effects on DOC flux below the $5-\mathrm{cm}$ depth are associated with sorption and desorption parameters (Figure 5). In the surface soil, varying the soluble fraction of microbial turnover between 0.1 and 0.5 altered the fluxes by $13 \%$, with lower DOC fluxes in the low-solubility case. Altering the bioavailability of DOC or the soluble fraction of the microbial pool between the parameters shown in Table 4 did not affect DOC fluxes out of the surface layer. Comparisons of modeled microbial turnover to DOC fluxes indicate that layer-to-layer DOC fluxes could support approximately $6 \%$ of the surface layer microbial turnover and $10 \%-35 \%$ of $20-\mathrm{cm}$ and $50-\mathrm{cm}$ depth microbial turnover, with the remainder of the $\mathrm{C}$ substrate provided by root inputs and the turnover of the slow and passive SOM pools.

The model simulated the carbon content of the surface $60 \mathrm{~cm}$ to within $6 \%$ of the values of $8200 \mathrm{~g}$ $\mathrm{C} \mathrm{m}^{-2}$ presented for Harvard Forest by Gaudinski and others (2000) when DOC fluxes were included in the model. Total soil carbon to $60 \mathrm{~cm}$ was $8600 \mathrm{~g} \mathrm{C}$ $\mathrm{m}^{-2}$ for simulations with DOC and root carbon inputs and $6400 \mathrm{~g} \mathrm{C} \mathrm{m}^{-2}$ for simulations with root inputs only. When soil carbon profiles were generated using only roots and surface litter inputs as $\mathrm{C}$ sources (that is, with DOC generation and transport turned off in the model), the content and distribution of SOC along the soil profile was significantly altered. The elimination of DOC transport in the model reduced the total column SOC content by approximately $25 \%$, with the largest effects on the SOC content of the $10-30 \mathrm{~cm}$ layer. The inclusion of DOC in the model led to a more moderate decline of carbon with depth relative to the no-DOC case (Figure 6).

Variation in both the sorption and bioavailability parameters has a large effect on both DOC flux rates and the SOM C content of the upper layers of soil. Variation in the sorption and desorption parameters (Table 4) caused as much as $60 \%$ variation in the modeled SOC content. The effect of stabilization appears to be limited to the top few layers of the soil. For these particular simulations, there was sufficient sorption capacity in the lower soil layers to dampen any effect of sorption parameter variation on DOC fluxes or SOC content of the deep soils (Figures 3 and 5).

\section{Discussion}

The algorithms described here represent a generalized approach for simulating DOC fluxes in soils to improve the simulation of soil $\mathrm{C}$ distributions and dynamics. These approaches are compatible with most ecosystem model SOM pool structures and could be tested in a number of ecosystems using the relationships and values presented here. Although we do not provide a detailed validation of the DOC model, the results indicate that a sorption-based layered soil model can capture the general patterns in DOC fluxes and concentrations with soil depth-at least in temperate forests, where DOC 

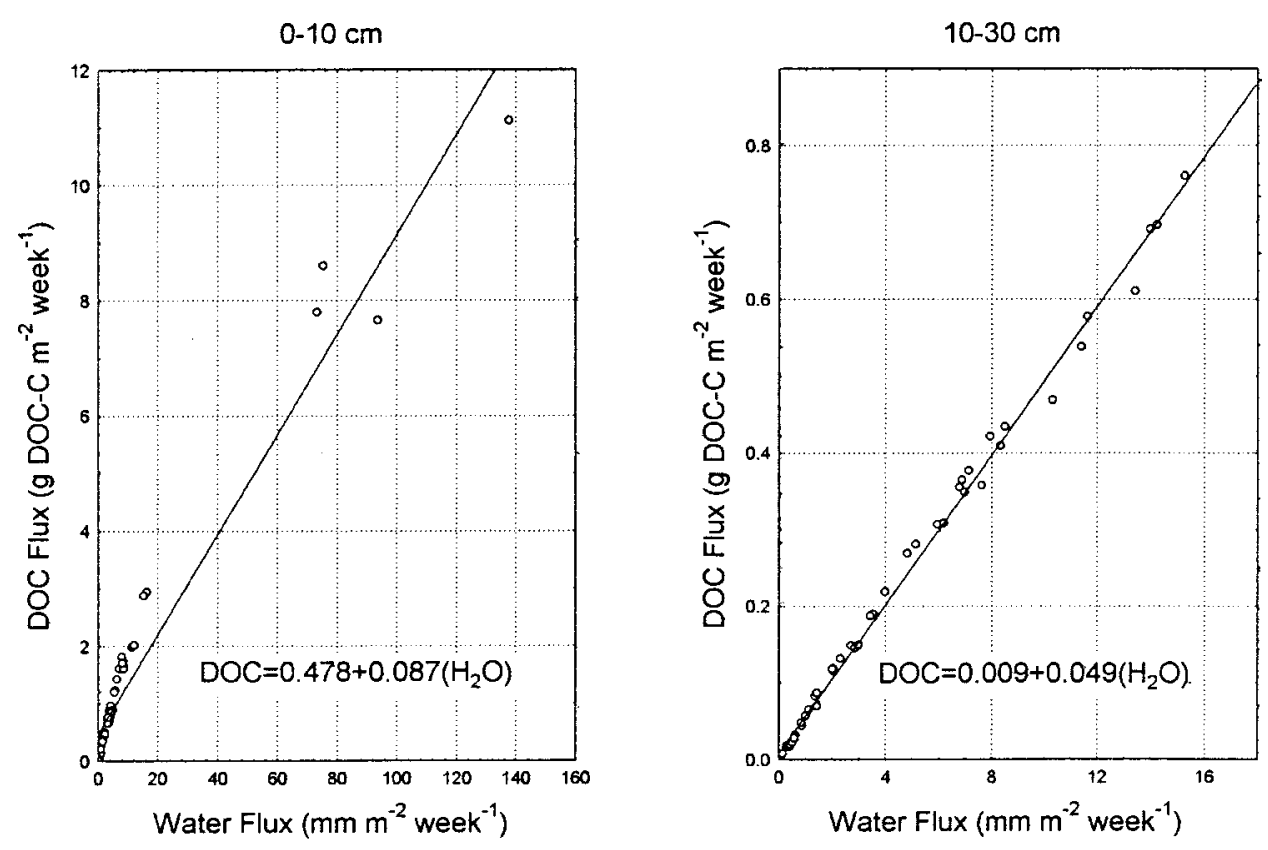

Figure 4. Relationships between water fluxes and DOC fluxes on a weekly basis for soil depths of $0-10,10-30$, $30-70$, and $70-140 \mathrm{~cm}$.
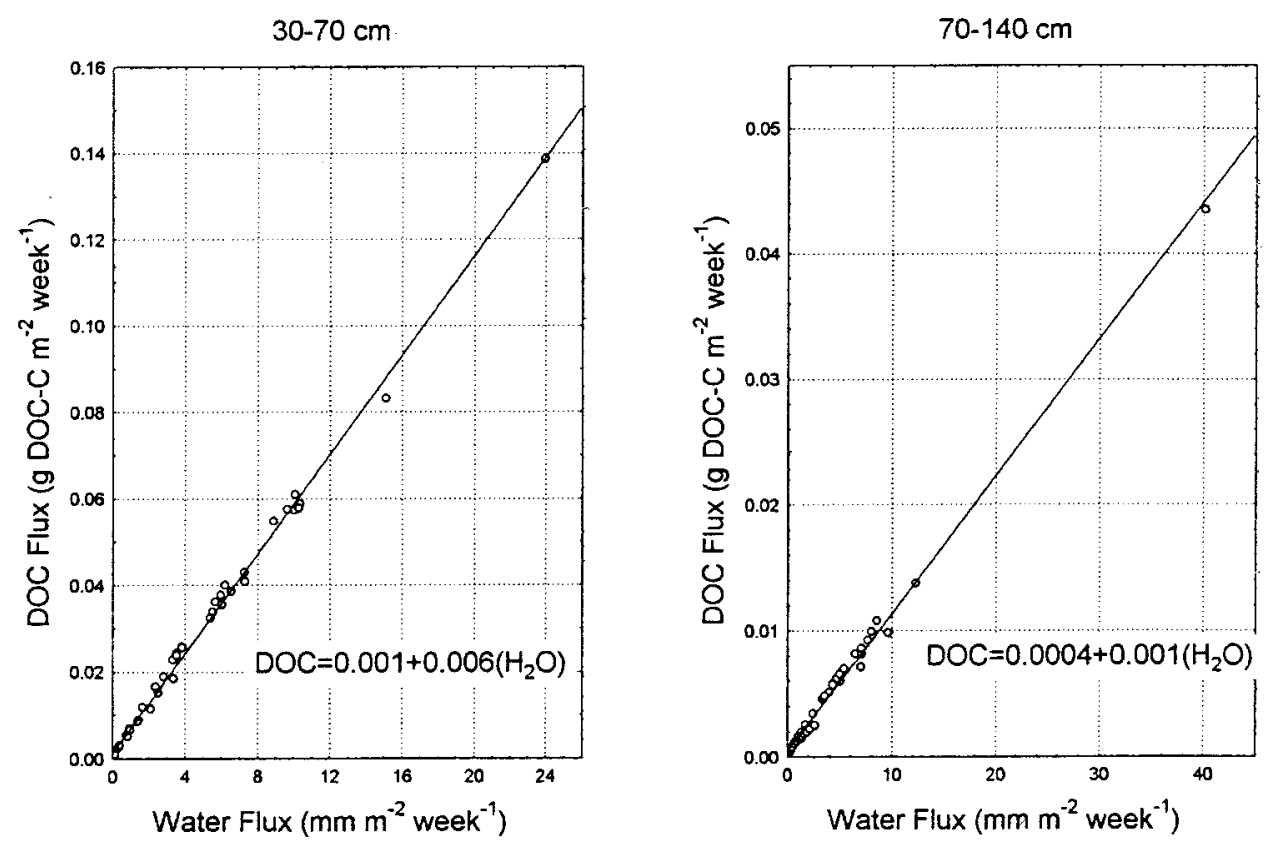

flux data is readily available. But the results also underscore the need for more detailed field experiments in several key areas.

One of the main model predictions is that hydrologic and soluble carbon flows should be closely related. This result is not surprising since DOC and water must move together in the model, but it highlights the need to identify the basic quantitative relationships between water and carbon flux. Although fundamental to the model, hydrologic-DOC flux re-

lationships can be difficult to determine empirically. One of the difficult issues involved in the comparison of an hourly time step model such as Terraflux with field data lies in the disconnect between model time steps and the availability of field data.

In the modeled fluxes of DOC from the litter layer, a large fraction of the flux is associated with rain events of less than $1 \mathrm{~mm}$ per day. This relationship differs from DOC/hydrology relationships in soils due to the limited water-holding capacity of 


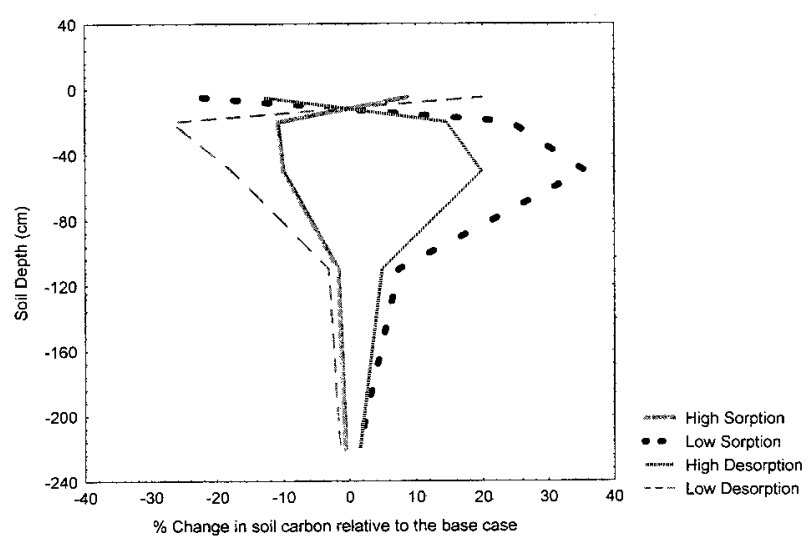

Figure 5. Sensitivity of soil carbon distributions to variation in sorption and desorption parameters.

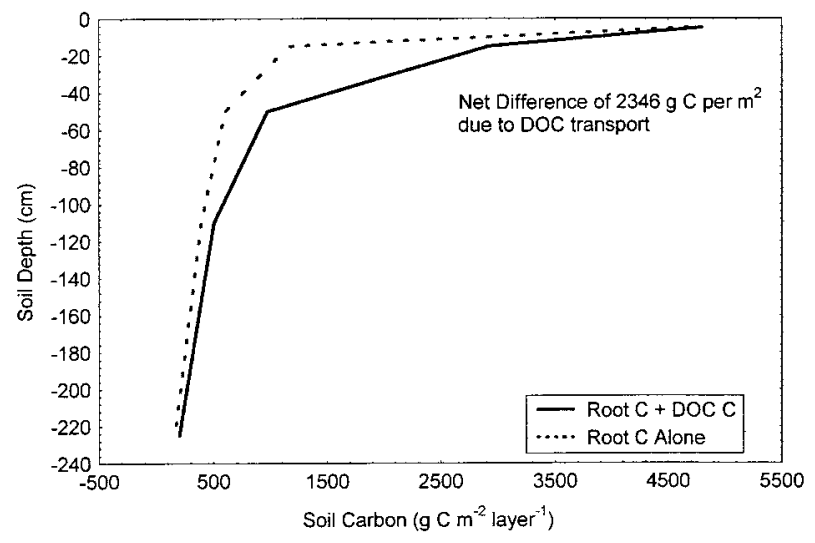

Figure 6. Soil organic carbon distribution curves for simulations using roots as the sole source of carbon (dashed line) and roots + DOC transport (solid line) as dual sources of carbon to lower soil layers. Soil carbon is given in $\mathrm{g} \mathrm{C} \mathrm{m}^{-2}$ and is integrated for each modeled soil layer.

the litter layer. The potentially soluble $\mathrm{C}$ pool in the litter layer can be rapidly depleted as the surface layer flushes during storm events. In the surface soils where there is a large water-holding capacity, flushing events are more rare but they are responsible for the transfer of a substantial fraction of DOC to lower layers. These two issues are important because it is difficult to measure small fluxes in a field setting due to constraints on sample collection and the need for sufficient volumes of soil solution for analysis. In the opposite case of very large soil flushing events, it is frequently difficult to sample during storms or immediately afterward.

The DOC model presented here predicts that these periods may be critical to capturing the overall flux of DOC out of surface soils. However, these predictions require new field measurements. In all layers, the modeled hydrologic and DOC fluxes are closely coupled. At the watershed scale, DOM concentrations are often proportional to runoff (Hobbie and Likens 1973; Dahm 1981; Hornberger and others 1994; McDowell and Asbury 1994; Newbold and others 1995; Hudson and others 1996; Hinton and others 1997). Our simulations suggest that similar relationships should also hold for within-ecosystem DOC fluxes.

The second pattern that emerges from the modeling exercise is the strength of physical rather than the biological controls over DOC export flux, even in surface soils. In these simulations, the most important mechanistic controls over DOC fluxes are the sorption properties of the soil. This finding is consistent with studies of DOC fluxes through soils that show more attenuation of DOC concentrations with depth in soils containing high clay content than in coarse-textured or highly organic soils (Moore and Jackson 1989; Nelson and others 1993; McClain and others 1997). However, the prediction that biological factors play little role in controlling fluxes below $20 \mathrm{~cm}$ requires detailed field-based testing. An implicit competition exists between physical and biological fates for DOC in the model; this competition should be explored in field experiments to evaluate whether the apparent dominance of physical factors is reasonable (see Kalbitz and others 2000 for a further discussion of this point).

DOC stabilization reactions appear to have the largest effects on soil carbon distribution in the surface layers of soils. Even a relatively weak sorbing soil $(m=0.3)$ exhibits strong retention of DOC in the surface zones. The modeled effects of sorption and desorption parameters reflected a somewhat complicated relationship between sorption dynamics and soil C content. Soils with high sorption or low desorption capacity tended to have higher surface $(0-10 \mathrm{~cm})$ carbon than low-sorption/high-desorption capacity soils; but at lower soil depths, the low-sorption/high-desorption simulations showed greater carbon accumulations at 10$100 \mathrm{~cm}$. The model results suggest that there is a tradeoff between the tendency of a soil to stabilize carbon and the localization of that carbon in the upper soil layers, where overall rates of decomposition are faster. In the case of the low-sorption/ high-desorption simulations, more soluble carbon was stabilized onto lower soil surfaces where decomposition rates were slower, resulting in greater carbon storage in subsurface soils. These trends between sorption parameters and soil carbon content can be tested as more studies of sorption isotherms and carbon distributions become available.

The model predictions also suggest that increases 
in the stabilization capacity of surface soils may, somewhat paradoxically, lead to lower total soil column carbon. An important caveat to this model result is that we assumed that DOC was stabilized into an intermediate residence time pool (the "slow" pool). It is clear that the residence time of the stabilized carbon is critical to determining the overall effect of sorption on soil carbon content. Additionally, our simulations did not include a sophisticated representation of the saturation of soil DOC stabilization capacity. Residence time and stabilization capacity are clearly important to understanding the capacity of soils to stabilize carbon.

The relatively weak microbial control over net DOC fluxes through soils is an interesting result of these analyses. The close linkages between microbial and DOC dynamics have been the subject of many ecological studies, and there appear to be clear links between microbial turnover and DOC production and/or DOC concentrations and microbial activity (Yavitt and Fahey 1986; McDowell and Likens 1988; Qualls and Haines 1992; Jandl and Sollins 1997; Moller and others 1999). Our modeling analyses do not contradict a close relationship between DOC production and microbial dynamics, but they suggest that the primary control over DOC export from soils is more likely to be physical than biological. However, the potential for DOC to support microbial activity (particularly in the lower layers of the soil) strengthens the argument that soil decomposition fluxes should be coupled to soil water fluxes, not only by moisture controls over decomposition rates but also through hydrologic controls over DOC transport (substrate availability).

Soluble carbon transport through soils plays an important role in the simulation of SOM distributions and dynamics in soil profiles. Simpler models of multilayer soil carbon dynamics based on root C inputs alone may not be sufficient for accurate predictions of soil $\mathrm{C}$ distributions. The difference between root and DOC inputs is especially clear in the vertical distribution of soil carbon within the profile. Several compatibility issues arise when developing single compared with multilayer soil biogeochemistry models; these details are important considerations for the incorporation of a DOC flux model within an existing ecosystem model. In the most common types of ecosystem models, the carbon dynamics of only the top $10-20 \mathrm{~cm}$ of a soil profile are simulated and the dynamics of this layer must support all the observed carbon flux from terrestrial soils. Experimental data suggest that the top $20 \mathrm{~cm}$ contribute only $55 \%-80 \%$ of the total soil C flux (Jobbagy and Jackson 2000). Development of a multilayered soil model must address the difference between the $55 \%-80 \%$ of $\mathrm{C}$ that is actually respired from the top layers and the $100 \%$ represented by a typical single layer model.

\section{Conclusions}

DOC fluxes through soils are a relatively large source of carbon for microbial activity and represent a small but potentially important ecosystem C loss pathway. Studies of DOC fluxes have centered on temperate forest soils, but fluxes of soluble carbon through surface soils should be an important component of internal ecosystem C cycling even in systems with low net hydrologic export of DOC. Reviews of studies of DOC fluxes, sorption dynamics, and microbial-DOC linkages indicate that virtually all soils have some capacity for DOC stabilization; these physical factors are likely responsible for the decline in DOC fluxes with soil depth (rather than microbial utilization of soluble compounds). There is strong evidence of links between microbial activity and DOC concentrations/fluxes, but more information is needed to define the role of DOC as a substrate and/or byproduct of microbial turnover. Our development of a sorption-based ecosystem model highlights the importance of DOC transport for the representation of layered soil carbon dynamics. DOC fluxes can account for the formation of $25 \%$ of the soil carbon in a temperate forest and a large fraction of subsurface microbial turnover. Numerous uncertainties limit the broad application of models of DOC/SOM linkages. In particular, more information is needed on the accuracy of sorption estimates, the residence time of sorbed carbon, and the relationships between DOC and hydrologic fluxes. Relatively small variations in these parameters can have a significant effect on estimates of both SOM carbon and DOC flux in the model presented here.

\section{ACKNOWLEDGMENTS}

We thank P. Vitousek, C. Field, P. Matson, T. Baisden, and two anonymous reviewers for providing helpful comments on earlier versions of this manuscript. This work was supported by grants from the USDA (IITF 96-CA-017) and NSF (INT 9602949) to P. Vitousek and J. Neff and a NASA ESSP Predoctoral Fellowship to J. Neff. G. Asner was supported by the Sellers-Mooney-Randall-Fung NASA IDS project and NASA New Investigator Program grant number NAG5-8709.

\section{REFERENCES}

Albrecht A, Angers DA, Beare MH, Blanchart E. 1998. Soil aggregation, soil organic matter and soil biota interactions: 
implications for soil fertility recapitalization in the tropics. Cahiers Agri 7:357-363

Asner GP, Bateson CA, Privette JL, El Saleous NZ, Wessman CA. 1998. Vegetation structural effects on carbon uptake using satellite data fusion and inverse modeling. J Geophys Res 103:28839-38853

Asner GP, Townsend AR, Riley W, Matson PA, Neff JC, Cleveland CC. Physical and biogeochemical controls of terrestrial ecosystem response to nitrogen deposition. Biogeochemistry. Forthcoming

Asner GP, Wessman CA. 1997. Scaling PAR absorption from the leaf to landscape level in spatially heterogeneous ecosystems. Ecol Model 103:81-97

Beck T, Joergensen G, Kandeler E, Makeschin F, Nuss E, Oberholzer HR, Scheu S. 1997. An interlaboratory comparison of ten different ways of measuring soil microbial biomass C. Soil Biol Biochem 29:1023-1032

Biondini M, Klein DA, Redente EF. 1988. Carbon and nitrogen losses through root exudation by Agropyron cristatum, Agropyron smithii, and Bouteloua gracilis. Soil Biol Biochem 20:477482

Boissier JM, Fontvieille D. 1993. Characterization of dissolved organic carbon in cleared forest soils converted to maize cultivation. Soil Biol Biochem 25:1257-1261

Bonan GB. 1995. Land-atmosphere CO2 exchange simulated by a land surface process model coupled to an atmospheric general circulation model. J Geophys Res 100:2817-2831

Bonan GB. 1996. THe NCAR land surface model (LSM version 1.0) coupled to the NCAR community climate model. NCAR technical note NCAR/TN-429+STR, National Center for Atmospheric Research Boulder, CO 171 pp.

Boyer EW, Hornberger GM, Bencala KE, McKnight DM. 1996. Overview of a simple model describing variation of dissolved organic carbon in an upland catchment. Ecol Model 86:183188

Brinkmann W. 1985. Studies on hydrobiogeochemistry of a tropical lowland forest system. Geojournal 11:89-101

Brooks PD, McKnight DM, Bencala KE. 1999. Relationship between over-winter soil heterotrophic activity and DOC export in high elevation catchments. Water Resources Res 35:18951902

Burford JR, Bremner JM. 1975. Relationships between dentrification capacities of soils and total water soluble and readily decomposable soil organic matter. Soil Biol Biochem 7:389394

Chapin FS. 1995. New cog in the nitrogen cycle. Nature 377: 199-200

Chin-Leo G, Kirchman DL. 1990. Unbalanced growth in natural assemblages of marine bacterioplankton. Marine Ecol Prog Series 63:1-8

Christ MJ, David MB. 1996. Temperature and moisture effects on the production of dissolved organic carbon in a spodosol. Soil Biol Biochem 28:1191-1199

Christensen BT. 1996. Carbon in primary and secondary organomineral complexes. Adv Soil Sci 24:97-165

Cook BD, Allan DL. 1992. Dissolved organic carbon in old field soils: total amounts as a measure of available resources for soil mineralization. Soil Biol Biochem 24:595-600

Corre MD, Schnabel RR, Shaffer JA. 1999. Evaluation of soil organic carbon under forests, cool-season and warm-season grasses in the northeastern US. Soil Biol Biochem 31:15311539
Cosby BJ, Hornberger GM, Galloway JN, Wright RF. 1985. Modeling the effects of acid deposition: assessment of a lumped parameter model of soil and streamwater chemistry. Water Resources Res 21:51-63

Cronan CS, Aiken GR. 1985. Chemistry and transport of soluble humic substances in forested watersheds of the Adirondack Park, New York, USA. Geochim Cosmochim Acta 49:16971706

Currie WS, Aber JD. 1997. Modeling leaching as a decomposition process in humid montane forests. Ecology 78:1844-1860

Currie WS, Aber JD, McDowell WH, Boone RD, Magill AH. 1996. Vertical transport of dissolved organic $\mathrm{C}$ and $\mathrm{N}$ under long-term $\mathrm{N}$ amendments in pine and hardwood forests. Biogeochemistry 35:471-505.

Czech D, Kappen L. 1997. Field measurements of carbon leaching from leaves in beech and alder forests of northern Germany. Flora 192:209-215

Dahm CN. 1981. Pathways and mechanisms for removal of dissolved organic carbon from leaf leachate in streams. Can J Fish Aqua Sci 39:68-76.

Dalva M, Moore RE. 1991. Sources and sinks of dissolved organic carbon in a forested swamp catchment. Biogeochemistry 15: $1-19$

David MB, Vance GF, Krzyszowska AJ. 1995. Carbon controls on spodosol nitrogen sulfur and phosphorus cycling. In: McFee WM, Kelly JM editors. Carbon forms and functions in forest soils. Madison (WI): Soil Science Society of America. p 329354

Dosskey MG, Bertsch PM. 1997. Transport of dissolved organic matter through a sandy forest soil. Soil Sci Soc Am J 61:920927

Fernandez IJ, Lawrence GB, Son YH. 1995. Soil-solution chemistry in a low-elevation spruce-fir ecosystem, Howland, Maine. Water Air Soil Pollution 84:129-145

Field CB, Randerson JT, Malmstrom CT. 1995. Ecosystem net primary production: combining ecology and remote sensing. Remote Sensing Environ 51:74-88

Furrer G, Sollins P, Westall JC. 1990. The study of soil chemistry through quasi-steady-state models: II. Acidity of soil solution. Geochim Cosmochim Acta 54:2363-2374

Gaudinski JB, Trumbore SE, Davidson EA, Zheng S. 2000. Soil carbon cycling in a temperate forest: radiocarbon-based estimates of residence times, sequestration rates and partitioning of fluxes. Biogeochemistry 51:33-69

Göedde M, David MB, Christ MJ, Kaupenjohann M, Vance GF. 1996. Carbon mobilization from the forest floor under red spruce in the northeastern U.S.A. Soil Biol Biochem 28:11811189

Gosz JR, Likens GE, Bormann FH. 1973. Nutrient release from decomposing leaf and branch litter in the Hubbard Brook forest, New Hampshire. Ecol Monogr 43:173-191

Gregory PJ, Atwell BJ. 1991. The fate of carbon in pulse-labeled crops of barley and wheat. Plant Soil 136:205-214

Guggenberger G. 1994. Acidification effects on dissolved organic matter mobility in spruce forest ecosystems. Environ Int 20: $31-41$

Guggenberger G, Zech W. 1992. Retention of dissolved organic carbon and sulfate in aggregated acid forest soils. J Environ Qual 21:643-653

Hedin LO, Armesto JJ, Johnson AH. 1995. Patterns of nutrient loss from unpolluted old-growth temperate forest: evaluation of biogeochemical theory. Ecology 76:493-509 
Hinton MJ, Schiff SL, English MC. 1997. The significance of storms for the concentration and export of dissolved organic carbon from two Precambrian Shield catchments. Biogeochemistry 36:67-88

Hobbie JE, Likens GE. 1973. Output of phosphorus, dissolved organic carbon and fine particulate carbon from Hubbard Brook watersheds. Limnol Oceanogr 18:734-742

Hope D, Billett MF, Cresser MS. 1994. A review of the export of carbon in river water: fluxes and processes. Environ Pollut 84:301-324

Hornberger GM, Bencala KE, McKnight DM. 1994. Hydrological controls on dissolved organic carbon during snowmelt in the Snake River near Montezuma, Colorado. Biogeochemistry 25: 147-165

Hudon C, Morin R, Bunch J, Harland R. 1996. Carbon and nutrient output from the Great Whale River (Hudson Bay) and a comparison with other rivers around Quebec. Can J Fish Aquat Sci 53:1513-1525

Jandl R, Sollins P. 1997. Water-extractable soil carbon in relation to the belowground carbon cycle. Biol Fertil Soils 25:196-201

Jardine PM, Weber NL, McCarthy JF. 1989. Mechanisms of dissolved organic adsorption on soil. Soil Sci Soc Am J 53: $1378-1385$

Jobbagy EG, Jackson RG. 2000. The vertical distribution of soil organic carbon and its relation to climate and vegetation. Ecol Appl. 10:470-483

Kaiser K, Guggenberger G, Zech W. 1996. Sorption of DOM and DOM fractions to forest soils. Geoderma 74:281-303

Kaiser K, Zech W. 1998. Soil dissolved organic matter sorption as influenced by organic and sesquioxide coating and sorbed sulfate. Soil Sci Soc Am J 62:129-136

Kalbitz K, Solinger S, Park JH, Michalzik B, Matzner E. 2000. Controls on the dynamics of dissolved organic matter in soils: a review. Soil Sci 165:277-304

Kielland K. 1994. Amino acid absorption by arctic plans: implications for plant nutrition and nitrogen cycling. Ecology 75 : $2373-2383$

Kling GW, Kipphut GW, Miller MC. 1991. Arctic lakes and streams as gas conduits to the atmosphere: implications for tundra carbon budgets. Science 251:298-301

Kling GW, Kipphut GW, Miller MC. 1992. The flux of $\mathrm{CO}_{2}$ and $\mathrm{CH}_{4}$ from lakes and rivers in arctic Alaska. Hydrobiologia $240: 23-36$

Koprivnjak JF, Moore TR. 1992. Sources, sinks and fluxes of dissolved organic carbon in subarctic fen catchments. Arctic Alpine Res 24:204-210

Lajtha K, Seely B, Valiela I. 1995. Retention and leaching losses of atmospherically-derived nitrogen in the aggrading coastal watershed of Waquoit Bay, MA. Biogeochemistry 28:33-54

Likens GE, Galloway JN. 1983. The composition and deposition of organic carbon in precipitation. Tellus 35B:16-24

McBride MB. 1994. Environmental chemistry of soils. Oxford University Press

McClain ME, Richey JE, Brandes JA, Pimentel TP. 1997. Dissolved organic matter and terrestrial-lotic linkages in the central Amazon basin of Brazil. Global Biogeochem Cycles 11: 295-312

McDowell WH. 1998. Internal nutrient fluxes in a Puerto Rican rain forest. J Trop Ecol 14:521-536

McDowell WH, Asbury CE. 1994. Export of carbon, nitrogen and major ions from three tropical montane watersheds. Limnol Oceanogr 39:111-125

McDowell WH, Likens GE. 1988. Origin, composition and flux of dissolved organic carbon in the Hubbard Brook Valley. Ecol Monogr 58:177-195

McDowell WH, Wood T. 1984. Podzolization: soil processes control dissolved organic carbon concentrations in stream water. Soil Sci 137:23-32

Meyer, JL, Tate, CM. 1983. The effects of watershed disturbance on dissolved organic carbon dynamics of a stream. Ecology 64:33-44.

Michalzik B, Matzner E. 1999. Dynamics of dissolved organic nitrogen and carbon in a Central European Norway spruce ecosystem. Eur J Soil Sci 50:579-590

Moller J, Miller M, Kjoller A. 1999. Fungal-bacterial interaction on beech leaves: influence on decomposition and dissolved organic carbon quality. Soil Biol Biochem 31:367-374

Moore TR. 1989. Dynamics of dissolved organic carbon in forested and disturbed catchments, Westland, New Zealand: 1. Maimai. Water Resources Res 25:1321-1330

Moore TR, de Souza W, Koprivnjak JF. 1992. Controls on the sorption of dissolved organic carbon by soils. Soil Sci 154:120129

Moore TR, Jackson RJ. 1989. Dynamics of dissolved organic carbon in forested and disturbed catchments, Westland, New Zealand: 2. Larry River. Water Resources Res 25:1330-1341

Nasholm T, Ekblad A, Nordin A, Giesler R, Hogberg M, Hogberg P. 1998. Boreal forest plants take up organic nitrogen. Nature 392:914-916

Neff JC. 1999. Dissolved organic element dynamics in terrestrial ecosystems [dissertation]. Stanford (CA): Stanford University $92 \mathrm{pp}$

Neff JC, Hobbie SE, Vitousek PM. 2000. Controls over dissolved organic $\mathrm{C}, \mathrm{N}$ and $\mathrm{P}$ fluxes and stoichiometry in tropical soils of varying nutrient availability. Biogeochemistry. 51:283-302

Nelson PN, Baldock JA, Oades JM. 1993. Concentration and composition of dissolved organic carbon in streams in relation to catchment soil properties. Biogeochemistry 19:27-50

Newbold JD, Sweeney BW, Jackson JK, Kaplan LA. 1995. Concentrations and export of solute from six mountain streams in northwestern Costa Rica. J North Am Benthol Soc 14:21-37

Nielsen KE, Ladekarl UL, Nornberg P. 1999. Dynamic soil processes on heathland due to changes in vegetation to oak and Sitka spruce. Forest Ecol Manage 114:107-116

Nodvin SC, Driscoll CT, Likens GE. 1986. Simple partitioning of anions and dissolved organic carbon in a forest soil. Soil Sci $142: 27-35$

Parton WJ, Ojima DS, Cole DV, Schimel DS. 1994. A general model for soil organic matter dynamics: sensitivity to litter chemistry, texture and management. In: Quantitative modeling of soil forming processes. SSA Special Publication 39. Soil Science Society of America

Parton WJ, Schimel DS, Cole CV, Ojima DS. 1987. Analysis of factors controlling soil organic matter levels in Great Plains grasslands. Soil Sci Soc Am J 51:1173-1179

Prendergast JB. 1995. Soil water bypass and solute transport under irrigated pasture. Soil Sci Soc Am J 59:1531-1539

Qualls RG, Haines BL. 1992. Biodegradability of dissolved organic matter in forest throughfall, soil solution and stream water. Soil Sci Soc Am J 56:578-586 
Qualls RG, Haines BL, Swank WT. 1991. Fluxes of dissolved organic nutrients and humic substances in a deciduous forest. Ecology 72:254-266

Quideau SA, Bockheim JG. 1996. Vegetation and cropping effects on pedogenic processes in a sandy prairie soil. Soil Sci Soc Am J 60:536-545

Radulovich R, Sollins P, Baveye P, Solorzano E. 1992. Bypass water flow through unsaturated microaggregated tropical soils. Soil Sci Soc Am J 56:721-726

Randerson JT, Thompson MV, Fung IY. 1996. Substrate limitations for heterotrophs: implications for models that estimate the seasonal cycle of atmospheric $\mathrm{CO}_{2}$. Global Biogeochem Cycles 10:585-596

Richter DD, Markewitz D. 1996. Carbon changes during the growth of loblolly pine on formerly cultivated soil: The Calhoun Experimental Forest, USA. pp. 397-407. In Powlson, D.S., Smith P., and Smith, J. U. (eds). Evaluation of soil organic matter models: using existing long term data sets. NATO Advanced Science series 1, Global Environmental Change Vol. 38, Springer-Verlag, Berlin.

Santore RC, Driscoll CT, Aloi M. 1995. A model of soil organic matter and its function in temperate forest soil development. In: McFee WW, Kelly JM, editors. Carbon forms and functions in forest soils. Madison (WI): Soil Science Society of America. p 275-298

Schimel DS. 1995. Terrestrial ecosystems and the carbon cycle. Global Change Biol 1:77-91

Schimel DS, Braswell BH, Holland EA, McKeown R, Ojima DS, Painter TH, Parton WJ, Townsend AR. 1994. Climatic, edaphic, and biotic controls over storage and turnover of carbon in soils. Global Biogeochem Cycles 8:279-293

Schreiber JD, McDowell LL. 1985. Leaching of nitrogen phosphorus and organic-carbon from wheat straw residues: 1. Rainfall intensity. J Environ Qual 14:251-256

Seto M, Yanagiya K. 1983. Rate of carbon dioxide evolution from soil in relation to temperature and amount of dissolved organic carbon. Jap J Ecol 33:199-206

Seto M, Yui S. 1983. The amounts of dissolved organic carbon in the soil solutions of a forest and a farm soil in situ. Jap J Ecol 33:305-312

Sollins P, Hoffmann P, Caldwell BA. 1995. Stabilization and destabilization of soil organic matter: mechanisms and controls. Geoderma 74:65-105

Sollins P, McCorison FM. 1981. Nitrogen and carbon solution chemistry of an old growth coniferous forest watershed before and after cutting. Water Resources Res 17:1409-1418

Stevens DP, Cox JW. 1999. Pathways of phosphorus, nitrogen and carbon movement over and through texturally differentiated soils, South Australia. Aust J Soil Res 37:679-693

Toland DE, Zak DR. 1994. Seasonal patterns of soil respriation in intact and clear-cut northern hardwood forests. Can J For Res 24:1711-1716

Trumbore SE. 1993. Comparison of carbon dynamics in tropical and temperate soils using radiocarbon measurements. Global Biogeochem Cycles 7:275-290

Vance GF, David MB. 1992. Dissolved organic carbon and sulfate sorption by spodosol mineral horizons. Soil Sci 154:136-144

Vitousek PM, Hedin LO, Matson PA, Fownes JH, Neff JC. 1998. Within-system element cycles, input-output budgets and nutrient limitation. In: Groffman PM, Pace ML, editors. Successes, limitations and frontiers in ecosystem science. New York: Springer. p 432-451

Waddington JJ, Roulet NT. 1997. Ground water flow and dissolved carbon movement in a boreal peatland. J Hydrol 191: $122-138$

Weigand H, Totsche KU. 1998. Flow and reactivity effects on dissolved organic matter transport in soil columns. Soil Sci Soc Am J 62:1268-1274

Yano Y, McDowell WH, Aber JD. 2000. Biodegradable dissolved organic carbon in forest soil solution and effects of chronic nitrogen deposition. Soil Biol Biochem. 32:1743-1751

Yano Y, McDowell WH, Kinner NE. 1998. Quantification of biodegradable dissolved organic carbon in soil solution with flow-through bioreactors. Soil Sci Soc Am J 62:15561564

Yavitt JB, Fahey TJ. 1986. Litter decay and leaching from the forest floor in pinus contorta (lodgepole pine) ecosystems. J Ecol $74: 525-545$

Zsolnay A, Steindl H. 1991. Geovariability and biodegradability of the water-extractable organic material in an agricultural soil. Soil Biol Biochem 23:1077-1082 
Appendix Soil Sorption Parameters for a Variety of Soil Types and sites

\begin{tabular}{|c|c|c|c|c|c|c|c|}
\hline Site & $\begin{array}{l}\text { Soil Type } \\
\text { and Horizon }\end{array}$ & $\begin{array}{l}\text { Texture } \\
\text { Sa:Si:Cl }\end{array}$ & $\% \mathrm{C}$ & m & $-\mathrm{b}(\mathrm{mg} / \mathrm{g})$ & $\begin{array}{l}\text { Reactive } \\
\text { Soil Pool } \\
\text { (mg DOC/g } \\
\text { soil) }\end{array}$ & Reference \\
\hline & Ultisol & & & & & & $\begin{array}{l}\text { Qualls and Haines } \\
1992^{a}\end{array}$ \\
\hline \multirow[t]{2}{*}{ Coweeta } & $\mathrm{AB}$ & $32: 44: 24$ & $3.4 \%$ & 0.636 & 0.006 & 0.016 & \\
\hline & Spodosol & $\begin{array}{l}\text { sandy } \\
\text { loam }\end{array}$ & $2.6 \%$ & 0.583 & 0.028 & 0.06 & $\begin{array}{l}\text { Nodvin and } \\
\text { others } 1986\end{array}$ \\
\hline \multirow[t]{5}{*}{ Hubbard Brook } & BhS2, BhS3 & & & & & & \\
\hline & Noncarbonate & & & & & & $\begin{array}{l}\text { Kaiser and others } \\
1996^{b}\end{array}$ \\
\hline & Alfisol & & & & & & \\
\hline & A & & & 0.57 & 0.41 & 0.95 & \\
\hline & $\mathrm{E}$ & & & 0.51 & 0.19 & 0.38 & \\
\hline \multirow{22}{*}{$\begin{array}{l}\text { Norway Spruce Forrest- } \\
\text { Germany, the } \\
\text { Netherlands, and } \\
\text { Sweden }\end{array}$} & $2 \mathrm{~B}$ & & & 0.76 & 0.05 & 0.20 & \\
\hline & Inceptisol & & & & & & \\
\hline & A & & & 0 & 0.68 & .68 & \\
\hline & $\mathrm{Bw}$ & & & 0.54 & 0.12 & .27 & \\
\hline & $2 \mathrm{Bw}$ & & & 0.83 & 0.05 & .26 & \\
\hline & Inceptisol & & & & & & \\
\hline & A & & & 0.14 & 0.94 & 1.11 & \\
\hline & $\mathrm{Bw}$ & & & 0.46 & 0.29 & 0.54 & \\
\hline & $\mathrm{BC}$ & & & 0.65 & 0.10 & 0.29 & \\
\hline & Spodosol & & & & & & \\
\hline & A & & & 0.17 & 0.29 & 0.34 & \\
\hline & B & & & 0.08 & 0.07 & 0.08 & \\
\hline & $2 \mathrm{Bsl}$ & & & 0.80 & 0.05 & 0.27 & \\
\hline & Carbonate & & & & & & \\
\hline & Mollisol & & & 0.01 & 0.78 & 0.78 & \\
\hline & A & & & 0.70 & 0.20 & 0.59 & \\
\hline & $\mathrm{Bw}$ & & & 0.28 & 0.00 & 0.00 & \\
\hline & $\mathrm{C}$ & & & & & & \\
\hline & Inceptisol & & & 0.07 & 0.61 & 0.66 & \\
\hline & A & & & 0.31 & 0.18 & 0.26 & \\
\hline & Bw & & & 0.54 & 0.11 & 0.25 & \\
\hline & $\mathrm{CB}$ & & & & & & \\
\hline \multirow{9}{*}{$\begin{array}{l}\text { Southern Quebec, } \\
\text { Vegetation Unknown }\end{array}$} & Inceptisol & & & & & & Moore and others \\
\hline & B & $67: 28: 5$ & 1.54 & $0.48(0.03)$ & $0.11(0.02)$ & $0.21(0.03)$ & \\
\hline & $\mathrm{C}$ & $76: 21: 3$ & 0.44 & $0.32(0.08)$ & $0.08(0.02)$ & $0.15(0.05)$ & \\
\hline & Spodosol & & & & & & \\
\hline & A & $73: 22: 5$ & 1.76 & $0.43(0.09)$ & $0.34(0.07)$ & $0.78(0.34)$ & \\
\hline & B & $86: 11: 3$ & 2.21 & $0.49(0.04)$ & $0.18(0.02)$ & $0.43(0.09)$ & \\
\hline & $\mathrm{C}$ & $90: 7: 3$ & 0.45 & $0.35(0.04)$ & $0.07(0.01)$ & $0.23(0.12)$ & \\
\hline & $\begin{array}{l}\text { Inceptisol/ } \\
\text { Mollisol }\end{array}$ & & & & & & \\
\hline & B & $55: 40: 5$ & 0.41 & 0.16 & 0.08 & 0.10 & \\
\hline \multirow[t]{4}{*}{$\begin{array}{l}\text { Mixed Northern } \\
\text { Hardwood Forest }\end{array}$} & Inceptisol & & & & & & $\begin{array}{l}\text { Dalva and Moore } \\
\quad 1991\end{array}$ \\
\hline & Bhf & & 5.8 & 0.56 & 0.54 & 1.23 & \\
\hline & $\mathrm{Bm}$ & & 1.2 & 0.63 & 0.12 & 0.32 & \\
\hline & $\mathrm{C}$ & & 1.4 & 0.73 & 0.14 & 0.52 & \\
\hline
\end{tabular}


Appendix (Continued)

\begin{tabular}{|c|c|c|c|c|c|c|c|}
\hline Site & $\begin{array}{l}\text { Soil Type } \\
\text { and HOrizon }\end{array}$ & $\begin{array}{l}\text { Texture } \\
\text { Sa:Si: } \\
\text { Cl }\end{array}$ & $\% \mathrm{C}$ & $\mathrm{m}$ & $-\mathrm{b}(\mathrm{mg} / \mathrm{g})$ & $\begin{array}{l}\text { Reactive } \\
\text { Soil Pool } \\
\text { (mg DOC/g } \\
\text { soil) }\end{array}$ & Reference \\
\hline \multirow{17}{*}{$\begin{array}{l}\text { Northeastern Hardwood } \\
\text { Forest }\end{array}$} & $\begin{array}{l}\text { Inceptisol/ } \\
\text { Spodosol }\end{array}$ & & & & & & \multirow{17}{*}{$\begin{array}{l}\text { Vance and David } \\
1992\end{array}$} \\
\hline & Ae & & 1.4 & 0.34 & 0.47 & 0.71 & \\
\hline & $\mathrm{Bf}$ & & 3.4 & 0.71 & 0.25 & 0.86 & \\
\hline & $\mathrm{Bm}$ & & 0.7 & 0.73 & 0.09 & 0.33 & \\
\hline & $\mathrm{C}$ & & 0.3 & 0.70 & 0.04 & 0.13 & \\
\hline & & & & & & & \\
\hline & Spodosols & & & & & & \\
\hline & B & & 5.1 & 0.81 & 0.33 & 1.73 & \\
\hline & B & & 3.7 & 0.86 & 0.32 & 2.28 & \\
\hline & $\mathrm{C}$ & & 1.5 & 0.62 & 0.39 & 1.02 & \\
\hline & $\mathrm{B}$ & & 9.8 & 0.86 & 0.71 & 5.07 & \\
\hline & B & & 6.9 & 0.85 & 0.72 & 4.80 & \\
\hline & $\mathrm{BC}$ & & 2.9 & 0.77 & 0.51 & 2.21 & \\
\hline & B & & 7.7 & 0.88 & 0.33 & 2.75 & \\
\hline & $\mathrm{B}$ & & 6.1 & 0.91 & 0.34 & 3.77 & \\
\hline & $\mathrm{BC}$ & & 4.4 & 0.90 & 0.31 & 3.10 & \\
\hline & $\mathrm{C}$ & & 1.8 & 0.89 & 0.38 & 3.45 & \\
\hline Tapajos National Forest, & Oxisol & & & & & & \\
\hline Santarem, Brazil & A & $37: 2: 61$ & 2.01 & 0.34 & 0.07 & 0.12 & Neff 1999 \\
\hline Tapajos National Forest, & Ultisol & & & & & & \\
\hline Santarem, Brazil & A & $86: 0: 14$ & 1.05 & 0.31 & 0.12 & 0.20 & Neff 1999 \\
\hline Luquillo Experimental & Oxisol? & & & & & & \\
\hline Forest, Puerto Rico & A & $?$ & ? & 0.21 & 0.003 & 0.01 & Neff 1999 \\
\hline
\end{tabular}

